\title{
Ownership Structure and Bank Risk-Taking: Empirical Evidence from the Middle East and North Africa
}

\author{
Yosra Hammami ${ }^{1,2}$ \& Adel Boubaker ${ }^{1,2}$ \\ ${ }^{1}$ Faculty of Economic Sciences and Management of Tunis, University of Tunis el Manar, Tunisia \\ ${ }^{2}$ International Finance Group, Tunisia \\ Correspondence: Yosra Hammami, Faculty of Economic Sciences and Management of Tunis, University of \\ Tunis el Manar, Tunisia. Tel: 216-23-125-083. E-mail: yosrahammami@yahoo.fr
}

Received: March 11, 2015

Accepted: April 20, 2015

Online Published: April 25, 2015

doi:10.5539/ibr.v8n5p271

URL: http://dx.doi.org/10.5539/ibr.v8n5p271

\begin{abstract}
This paper examines the impact of bank ownership structure on bank risk-taking. It used balance sheet information for around 72 commercial banks from 10 Middle East and North Africa (MENA) countries from 2000 to 2010. The main results emerged. After controlling for bank characteristics and country effects, we find that concentrated ownership structure is associated with an increase in bank risk-taking. Further, foreign-owned banks are more risked than Domestic-owned banks; however, Government-owned banks are more stable. For listed banks family ownership has positive impact on credit risk. So, family owners impose riskiest strategies when they hold higher stakes. For unlisted banks the effect of family and institutional ownership on risk is negative. Finally we conclude that the effect of owners identity on bank risk-taking depends on the fact that bank is listed or unlisted.
\end{abstract}

Keywords: bank risk-taking, Middle East and North Africa, ownership structure

\section{Introduction}

The last three decades are characterized by the occurrence of banking crises. The most recent is the collapse of financial markets in the United States resulting from the crisis of "subprime". This crisis is considered as the most intense crisis since the Great Depression of 1929-1932. Thus, we could see and assess the vulnerability of the economic system against excessive risk-taking. We could also cite as an example of financial crisis; the Russian financial crisis in 1998, the 1997 Asian crisis, the Mexican crisis of 1994-1995. These circumstances have prompted national and international agencies to give more importance to the regulation to limit bank risk. During the last twenty years, the banking systems have undergone major changes with banking deregulation, market integration, privatization and entries of privately owned banks. These changes have led to a restructuring of the shareholding and bank capital. Institutional ownership has become more important, leading to a transformation of the governance systems and change in the behavior of banks in terms of risk-taking (Barry et al., 2011). Shareholders' behavior and their incentives to take higher risk can be a legitimate explanation of bank risk-taking level.

Despite some primitive changes in Middle East and North Africa (MENA), some countries of the region have succeeded in introducing new eras in privatization, market-oriented financial institutions, and entries of privately owned banks of different organizational structure. Foreign banking sectors became a major force in the financial service industry in MENA region countries. For example, Lebanon was a leader in the late 1960s in welcoming foreign banks (Kobeissi \& Sun, 2010). Consequently, state banks have lost an important part of the market in some countries but still play an important role in many of them. After the recent financial crisis, policy-makers are examining to know whether they should reduce further the role of these banks (Farazi et al., 2011). These major changes introduced on the banking system created a move of the ownership structure and reinforced the need to examine their impact on banks' risk-taking behavior. The idea of this paper is to examine the relation between ownership structure and bank risk-taking for privately and publicly held banks that might have different objectives in terms of growth and risk-return strategies. To our knowledge, the number of studies that examined the ownership structure of banks and its impact on bank risk-taking in MENA countries are limited (Srairi, 2013). However a respectable number of research were interested in analyzing the determinants of efficiency and performance of banks in the following countries: Tunisia (Ben Naceur \& Goaied, 2008) Jordan (Isik, Omran, \& 
Gunduz, 2004), Egypt (Omran, 2007), Lebanon (Turk-Ariss, 2008). The study of Kobeissi and Sun (2010) was an exception, because the authors studied the impact of ownership structure on the performance of banks in 17 countries from the MENA region. Thus, our aim herein is to assess bank's risk-taking behavior by combining the two dimensions of ownership structure: concentration and nature.

The objective of this paper is to extend the current literature in MENA region related to the impact of ownership structure on bank risk-taking. Ownership structure and its effects on bank risk are an interesting line of research and were weakly studied in the context of MENA region. The contribution of this paper is to assemble and analyze detailed data on ownership structure of banks from MENA region, in order to respond to the following related questions. Is banks ownership dispersed or concentrated? If banks have a controlling owner, who tends to control it? What is the effect of a determined ownership structure on banks' risk-taking behavior? We use a panel of MENA commercial banks through the 2000-2010 period. We find that different ownership structures involve different levels of risk.

\section{Literature Review and Hypotheses Development}

According to theoretical and empirical literature, agency problem and risk-taking varies according to the nature of the shareholder. A simplest and traditional issue is the conflict between managers and shareholders defined by Jensen and Meckling (1976). According to the agency theory shareholders have diversified portfolio they are generally motivated to take more risk than managers that can guarantee more profitability for them. Banks' risk-taking behavior differs depending on the degree of ownership concentration. When it is dispersed, we may face a conflict between shareholders and managers. However, if ownership is concentrated, there is a mutation of this conflict to the relationship between shareholders and minority shareholders (Shleifer \& Vishny, 1997). According to Jensen and Meckling (1976), shareholders typically hold diversified securities portfolios and are therefore motivated to take more risks to maximize their profits. In contrast, managers are encouraged to accept less risk to protect their position in the bank and reputation (Demsetz \& Lehn, 1985; Jensen \& Meckling, 1976). Empirically, Saunders et al. (1990) were the first to study the effect of ownership structure on bank risk-taking. They predict that the managerial ownership impacts positively the level of credit risk and that banks controlled by shareholders adopt a higher level of risk than those controlled by managers. The results of researches that examined this relation were divergent. Some researchers concluded that it is negative and others indicated that the relation between ownership concentration and bank risk is U-Shaped (Anderson \& Fraser, 2000; Chen et al, 1998; Gordon \& Rosen, 1995).

\subsection{Ownership Concentration}

Theoretically, the answer to the question "how ownership concentration does affect bank risk-taking?" seems to be ambiguous. In fact, literature came up with different answers to this question. Jensen and Meckling (1976) and DeAngelo and DeAngelo (1985) argued that the wealth generated by holding a large share of capital can align the interests of block holders with those of minority shareholders. Shleifer and Vishny (1986) confirmed these results and argued that ownership concentration enhances corporate control by improving the monitoring. While, other studies suggested that ownership concentration may not reduce banks risk. Burkart et al. (1997) confirmed that tight outside ownership constitutes an expropriation threat that reduces managerial initiatives. Shleifer and Vishny (1997) argued that large shareholders may exercise control right to create private benefits at the expense of minority shareholders. Empirically, Leavine and Levine (2009) studied the relation between ownership concentration and the level of risk in 10 largest banks in 48 countries. They found that shareholders tend to accept a high level of risk. This result was confirmed by Haw et al. (2010) which provided that, in the Asian and European banks, the presence of the control block is associated with high levels of insolvency risk and volatility of profitability. Additionally, Shehzad et al. (2010) analyze data around 500 banks from more than 50 countries averaged over 2005-2007 period. They affirmed that concentrated ownership significantly reduces a banks' non-performing loans ratio, conditional on supervisory control and shareholders protection rights. Furthermore, ownership concentration improves the capital adequacy ratio conditional on the extent of shareholder protection.

H1: Different levels of ownership concentration imply different levels of risk.

\subsection{The Nature of Shareholders}

Government owned banks are usually run by bureaucrats who can benefit from highly concentrated control rights. The objectives of the political bureaucrats are often dictated by the public interest. In theory, the participation of government in the financial market was supported by two views; the development view and the political view. The first view, suggested that in some countries, the economic institutions are not developed, so, government ownership of strategic economic sectors such as banks is needed to accelerate growth and jumpstart 
financial and economic development (Kobeissi, 2010). The second view, suggested that government control companies and banks in order to control employment and benefit to supporters in return for votes assistances. Researches realized in this issue advance that state-owned banks have poorer loan quality and higher insolvency risk than privately-owned banks (Berger et al., 2007; Iannota et al., 2007). In the context of MENA countries Ben Nacer and Goaied (2008) analyzed the determinants of Tunisian banks performance. They found that government ownership has a negative effect of bank performance. This result was confirmed later by Farazy et al. (2011). Working with a panel of 10 MENA countries over the period 2005-2009, Srairi (2013) confirmed that government-owned banks display higher risk and have significantly greater proportions of non-performing loans than other banks. In addition, some researches show that foreign-owned banks perform more than other banks (Berger, 2006; Farazi et al., 2011; Micco et al., 2004).

Other aspects have been well established in the literature especially on the non-financial firms. First, family-firms are less efficient than other type of firms. The founders of such firms hold non-diversified investment portfolios. This situation prompts them to abandon taking more risk to achieve an optimized performance. These firms tend to invest in long-term profitable projects which promote the efficiency of their investment policy (Stein, 1988, 1989). In addition, James (1999) argues that family-owner has longer investment horizons that lead their firm to realize greater investment efficiency. However, managers are usually family members, so they are deprived of external expertise and may be less competitive than non-family firms (Morck et al., 2000). From theoretical perspective, family banks tend to maintain undiversified securities portfolio and more specifically less diverse than those of other shareholders, especially institutional investors. Thus, if the bank ruin, they risk being higher loser. Working with a panel of Asian banks before the Asian crisis of 1997, Leavine (1999) finds that family-owned banks usually suffer from their weak governance system and were among the most risky banks. Families attempt to use banks funds in financing their own projects.

Institutional investors can also shape the nature of corporate risk taking. In fact, institutional owners have the means to obtain information and skills needed to interpret and carry out the necessary oversight action (Barry et al., 2011). Several studies analyzed the impact of institutional shareholders on firm's performance (Pound, 1988; Elyasiani \& Jia, 2008); however, it does not provide conclusive results. Different institutional investors have different investment objectives and horizon, some choose to monitor the firm and control the management team, and other focus information gathering and short term trading profits. Barry et al. (2011) reported that institutional shareholders exert significant power within banks through their right to vote, and therefore, they can influence the decisions of managers in terms of risk-taking. They are usually experienced in data processing and managers' control.

H2: Different ownership structures imply different levels of risk.

\section{Methodology}

\subsection{Sample and Data Collection}

We collect the annual data from the annual report of banks, which provides information on financial statements and ownership structure. As explanatory variables, we consider first, the level of ownership concentration. Second, we classify banks by the nature of major shareholder as follow: government-owned banks, foreign-owned banks and domestic-owned banks. Third, we consider the percentage of stocks held by shareholders included into the following categories: managers/directors, institutional investors and family investors. We use a sample of an unbalanced panel from 2000-2010 for a set of MENA commercial banks from 10 countries namely: Oman, Kuwait, Qatar, United Arab Emirates, Lebanon, Jordan, Egypt, Tunisia, Morocco and Turkey. We identify 769 banks in bank scope database. We eliminate all non commercial banks, which leaves us with 149 banks from all countries of MENA region. Of these banks, we delete banks for which detailed data on ownership are not available in the annual reports. Also, we only select banks with a stable ownership structure by comparing the proportion of equity held by the main shareholders over the 2000-2010 period. This constraint is important to accurately analyze the impact of ownership structure on banks risk. The final sample consists of 72 commercial banks (see table 2, for further details on the distribution of banks by country).

\subsection{Measurement of Bank Risk}

We use different measures to assess the level of expositor to risk in bank organizations. First, we compute two different measures of assets risk; the standard deviation of Return on Equity (SDROE) and the standard deviation of Return on Assets (SDROA) (Barry et al., 2011). In addition, we calculate default risk; the Z-score. It is a measure of bank insolvency risk, frequently used by researchers (Barry et al., 2011; Laevine \& Levine, 2009; Tarazi et al., 2008). A high value of the Z-score implies a lower probability of bank failure, and it measures the distance from insolvency (Roy, 1952). Z-score defines insolvency as the state where losses exceed its equity 
$(\mathrm{E}<\pi)$. As credit risk measure we use the Gross Loan Provision to total loan ratio. This measure allows us to proxy assets quality. Riskier loans may produce higher interest income (Iannotta et al., 2008).

\subsection{Model Specification}

This paper examines the impact of ownership structure on bank risk-taking. To test the hypothesis defined above we use the following models. We note that we employ Generalized Listed Square (GLS) on annual bank data for the period 2000-2010.

\section{Model 1}

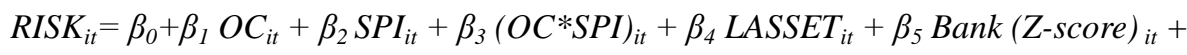

$$
\begin{aligned}
& \beta_{6} G D P / \text { CAPITA }_{i t}+\beta_{7} \text { CRISIS } S_{i t}+\mu_{i t}
\end{aligned}
$$

The equation above focuses on hypothesis 1 , as concentrated ownership affects bank risk-taking depending on regulation environment. I employ three separate levels of ownership concentration (OC1, OC2 and OC3), that constitute the entire sample; the intercept term would capture the omitted variables.

The model (2) focuses on hypothesis 2 . We note that private banks are consisted of foreign-owned private banks and domestic-owned private banks; we employ DOMESTIC, FOREIGN and GOVERNEMENT variables. In this model the omitted variable is DOMESTIC and the variables used explicitly are FOREIGN and GOVERNMENT.

\section{Model 2}

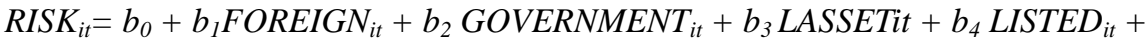

$$
\begin{aligned}
& b_{5} \text { Bank-Z-score }_{i t}+b_{6} \text { GDP/CAPITA }_{i t}+b_{7} \text { GCC }_{i t}+b_{8} \text { CRISIS }_{i t}+\mu_{i t}
\end{aligned}
$$

In order to analyze whether commercial banks with different ownership structures present significant differences in risk, we use model (3). This specification allows us to test the effect of different ownership combinations on bank risk-taking. It also gives us the opportunity to discover possible coalitions between different types of shareholders (Barry et al., 2011).

\section{Model 3}

$$
\begin{array}{r}
\text { Risk }_{i t}=\alpha_{0}+\alpha_{1} \text { Manager }_{i t}+\alpha_{2} \text { Directors }_{i t}+\alpha_{3} \text { Family }_{i t}+\alpha_{4} \text { Institutional }_{i t}+\alpha_{5} \text { LASSET }_{i t}+ \\
\alpha_{6} \text { Listed }_{i t}+\alpha_{7} \text { GDP/CAPITA }_{i t}+\alpha_{8} \text { Bank-Z-score }_{i t}+\mu_{i t}
\end{array}
$$

\begin{tabular}{|c|c|}
\hline Variables & Measurement \\
\hline \multicolumn{2}{|c|}{ Independent Variables } \\
\hline OC1 & Dummy variable that is one in case there is at least one owner with shareholdings greater than $10 \%$ and zero otherwise. \\
\hline $\mathrm{OC} 2$ & Dummy variable that is one in case there is at least one owner with shareholdings above $25 \%$ and zero otherwise \\
\hline OC3 & Dummy variable that is one in case there is a controlling owner with more than $50 \%$ of the shares and zero otherwise. \\
\hline GOVERNEMENT & Dummy variable takes the value (1) if State held more than $50 \%$ of bank capital and zero otherwise. \\
\hline FOREIGN & Dummy variable equal 1 if foreign shareholders held more than $50 \%$ of bank capital and zero otherwise. \\
\hline DOMESTIC & Dummy variable equal (1) if domestic shareholders held more than $50 \%$ of bank capital and zero otherwise. \\
\hline Manager & The proportion of equity held by manager \\
\hline Directors & The proportion of equity held by directors \\
\hline Family & The proportion of equity held by family members \\
\hline Institutional & The proportion of equity held by institutional investors \\
\hline \multicolumn{2}{|l|}{ Control variables } \\
\hline LASSET & The logarithm of total assets. \\
\hline LISTED & Dummy variable equal (1) if the bank is listed and zero otherwise \\
\hline Age & The age of the bank \\
\hline SPI & The index of minority shareholders protection \\
\hline GDP per capita & It measures the per capita income of own country \\
\hline Bank zscore & It captures the probability of a country's default banking system. \\
\hline CRISIS & Dummy variable takes (1) if the period studied is after the subprime crisis and zero otherwise. \\
\hline GCC & Dummy variable takes (1) if the country is member of Golf Cooperation Council and zero otherwise \\
\hline
\end{tabular}

\subsection{Explanatory Variables}

Table 1. Independent and control variables identification 


\section{Results}

\subsection{Trends in Bank Ownership in the MENA Region}

Referring to table 2 we see that bank (OC3) is frequent in Egypt (72.2\%), Lebanon (62.5\%) and Tunisia (64\%); however in Qatar there are no banks with concentrated ownership structure. As shown in table 3, the percentage of banks with concentrated ownership structure in MENA has been increasing from $40.62 \%$ in 2005 to $53.7 \%$ in 2010. We note that the proportion of state-owned banks has declined from $15.79 \%$ in 2007 to $9.61 \%$ in 2010 . This decline is accompanied by an increase in the average market share of foreign-owned banks (from $17.54 \%$ in 2007 to $23 \%$ in 2010), family-owned banks (from $7.02 \%$ in 2007 to $9.61 \%$ in 2010) and institutional-owned banks (from $7.02 \%$ in 2007 to $11.53 \%$ in 2010). We note that state-owned banks declined significantly after the crisis, but remained significant.

Table 2. Distribution of ownership concentration by country

\begin{tabular}{ccccccccccc}
\hline Ownership concentration & Jordan & Morocco & Tunisia & Turkey & Oman & Egypt & Kuweit & Libanon & UAE & Qatar \\
\hline OC1 & $100 \%$ & $100 \%$ & $100 \%$ & $82 \%$ & $100 \%$ & $100 \%$ & $45,50 \%$ & $100 \%$ & $100 \%$ & $100 \%$ \\
OC2 & $80 \%$ & $93 \%$ & $75,30 \%$ & $80,00 \%$ & $77 \%$ & $89 \%$ & $91 \%$ & $80 \%$ & $87 \%$ & $76,50 \%$ \\
OC3 & $14 \%$ & $46,40 \%$ & $64 \%$ & $44,20 \%$ & $19,20 \%$ & $72,20 \%$ & $45,50 \%$ & $62,50 \%$ & $60,86 \%$ & $0,00 \%$ \\
Nbre of banks & 7 & 4 & 13 & 15 & 6 & 4 & 2 & 12 & 5 & 4 \\
Listed banks & 6 & 4 & 8 & 11 & 5 & 3 & 2 & 5 & 4 & 3 \\
Unlisted banks & 1 & 0 & 5 & 4 & 1 & 1 & 0 & 7 & 1 & 1 \\
\hline
\end{tabular}

Table 3. Classification of MENA banks' categories by year

\begin{tabular}{lccccccccccc}
\hline Categories & 2000 & 2001 & 2002 & 2003 & 2004 & 2005 & 2006 & 2007 & 2008 & 2009 & 2010 \\
\hline OC3 & $40 \%$ & $41,70 \%$ & $53,85 \%$ & $50 \%$ & $45,45 \%$ & $40,62 \%$ & $46,94 \%$ & $45,62 \%$ & $49,25 \%$ & $51,56 \%$ & $53,70 \%$ \\
State & 0 & 0 & 0 & 0 & $9,10 \%$ & $9,67 \%$ & $12,76 \%$ & $15,79 \%$ & $12,31 \%$ & $11,29 \%$ & $9,61 \%$ \\
Private & $40 \%$ & $41,70 \%$ & $53,85 \%$ & $50 \%$ & $36,35 \%$ & $30,95 \%$ & $34,18 \%$ & $29,83 \%$ & $36,94 \%$ & $40,27 \%$ & $44,09 \%$ \\
Foreign & $30 \%$ & $25 \%$ & $23,07 \%$ & $28,57 \%$ & $22,73 \%$ & $19,35 \%$ & $21,27 \%$ & $17,54 \%$ & $21,54 \%$ & $20,97 \%$ & $23 \%$ \\
Domestic & $10 \%$ & $17 \%$ & $30,78 \%$ & $21,43 \%$ & $13,62 \%$ & $11,60 \%$ & $12,91 \%$ & $12,29 \%$ & $15,40 \%$ & $19,30 \%$ & $21,02 \%$ \\
Family & $0 \%$ & $8,33 \%$ & $15,38 \%$ & $7,14 \%$ & $9,09 \%$ & $6,45 \%$ & $6,38 \%$ & 7,02 & $9,24 \%$ & 9,67 & $11,53 \%$ \\
Institutional & $10 \%$ & $8,33 \%$ & $15,39 \%$ & $14,28 \%$ & $4,54 \%$ & $3,22 \%$ & $6,38 \%$ & $5,26 \%$ & $6,16 \%$ & $8,06 \%$ & $9,61 \%$ \\
\hline
\end{tabular}

Descriptive statistics of ownership nature are presented in table 4. It shows that approximately, $6 \%$ of banks have a dispersed ownership; they have no shareholders with more than $10 \%$ ownership stake. Almost $80 \%$ of banks have an owner with more than $25 \%$ of shares stake. Furthermore, approximately half $(47 \%)$ of banks have one or more owners with more than 50\% of share. We can conclude that in MENA countries, bank ownership structure is generally concentrated (Shehzad et al., 2010).

It shows that the major shareholder category is institutional shareholder with an average of $16.56 \%$ of equity. Foreign banks present $21.55 \%$ of total banks; this category of banks is strongly present in our sample. Managers and directors hold equity in the majority of banks. The average proportions of stocks they hold is relatively low (respectively $0.85 \%$ and $7.38 \%$ ) compared to the other owners. 
Table 4. Summary statistics

\begin{tabular}{|c|c|c|c|c|c|}
\hline Variables & Mean & Standard Deviation & Min & $\operatorname{Max}$ & Observations \\
\hline \multicolumn{6}{|c|}{ Panel A: Ownership structure variables } \\
\hline $\mathrm{OC} 1$ & 0.9443 & 0.1129 & 0 & 1 & 413 \\
\hline $\mathrm{OC} 2$ & 0.8062 & 0.0194 & 0 & 1 & 413 \\
\hline OC3 & 0.4624 & 0.0245 & 0 & 1 & 413 \\
\hline Foreign & 0.2058 & 0.0199 & 0 & 1 & 413 \\
\hline Government & 0.1307 & 0.0 .166 & 0 & 1 & 413 \\
\hline Domestic & 0.1428 & 0.0172 & 0 & 1 & 413 \\
\hline Institutionnal & 0.1656 & 0.2184 & 0 & 0.95 & 413 \\
\hline Family & 0.0937 & 0.1885 & 0 & 0.8976 & 413 \\
\hline Manager & 0.0085 & 0.0445 & 0 & 0.496 & 385 \\
\hline Directors & 0.0738 & 0.1782 & 0 & 0.9742 & 385 \\
\hline \multicolumn{6}{|c|}{ Panel B: Risk measures } \\
\hline SDROE & 0.0618 & 0.10729 & 0.00005 & 0.9718 & 413 \\
\hline SDROA & 0.0094 & 0.01083 & 0.00061 & 0.0546 & 411 \\
\hline Z-score & 31.585 & 20.5570 & 5.41816 & 68.657 & 408 \\
\hline LLP & 0.3355 & 0.0720 & 0 & 0.7555 & 387 \\
\hline \multicolumn{6}{|c|}{ Panel C: Banks specific variables } \\
\hline LAssets & 25.3208 & 365.6566 & 4.2452 & 76.6684 & 412 \\
\hline Age & 40.7829 & 25.2609 & 0.5 & 156 & 413 \\
\hline Listed & 0.74818 & 0.43458 & 0 & 1 & 413 \\
\hline \multicolumn{6}{|c|}{ Panel D: Countries specific variables } \\
\hline Bank Z-score & 29.5895 & 9.1754 & -0.4691 & 52.9322 & 413 \\
\hline GDP per capita & 6540.275 & 7801.39 & 1271.811 & 33288.11 & 413 \\
\hline SPI & 4.7222 & 0.8523 & 3 & 6 & 333 \\
\hline CRISE & 0.6271 & 0.4841 & 0 & 1 & 413 \\
\hline GCC & 0.1791 & 0.3839 & 0 & 1 & 413 \\
\hline
\end{tabular}


Table 5. Correlation matrix

\begin{tabular}{|c|c|c|c|c|c|c|c|c|c|c|c|c|c|c|}
\hline Variables & z-score & SDROE & SDROA & $\mathrm{OC} 1$ & $\mathrm{OC} 2$ & $\mathrm{OC} 3$ & SPR & $\begin{array}{l}\mathrm{SPR}^{*} \\
\mathrm{OC} 1\end{array}$ & $\begin{array}{l}\text { SPR* } \\
\text { OC2 }\end{array}$ & $\begin{array}{c}\mathrm{SPR}^{*} \\
\mathrm{OC} 3\end{array}$ & LISTED I & LASSETS & $\begin{array}{c}\text { Bank } \\
\text { (z-score) }\end{array}$ & $\begin{array}{l}\text { GDP/ } \\
\text { CAP }\end{array}$ \\
\hline z-score & 1 & & & & & & & & & & & & & \\
\hline SDROE & $\begin{array}{c}.432 * * \\
.000\end{array}$ & 1 & & & & & & & & & & & & \\
\hline SDROA & $\begin{array}{c}-.788^{*} \\
.000\end{array}$ & $\begin{array}{c}.399 * * \\
.000\end{array}$ & 1 & & & & & & & & & & & \\
\hline OC1 & $\begin{array}{l}.096 \\
.051\end{array}$ & $\begin{array}{l}-.095 \\
.052\end{array}$ & $\begin{array}{l}-.053 \\
.277\end{array}$ & 1 & & & & & & & & & & \\
\hline $\mathrm{OC} 2$ & $\begin{array}{l}.026 \\
.594\end{array}$ & $\begin{array}{l}.027 \\
.575\end{array}$ & $\begin{array}{l}-.024 \\
.616\end{array}$ & $\begin{array}{l}-.012 \\
.805\end{array}$ & 1 & & & & & & & & & \\
\hline OC3 & $\begin{array}{r}-.007 \\
.886\end{array}$ & $\begin{array}{l}.086 \\
.079\end{array}$ & $\begin{array}{l}.069 \\
.159\end{array}$ & $\begin{array}{c}.225^{* *} \\
.000\end{array}$ & & 1 & & & & & & & & \\
\hline SPR & $\begin{array}{l}-.045 \\
.445\end{array}$ & $\begin{array}{l}-.069 \\
.199\end{array}$ & $\begin{array}{l}.405 \\
.456\end{array}$ & $\begin{array}{c}-.127 * \\
.018\end{array}$ & $\begin{array}{l}.017 \\
.741\end{array}$ & $\begin{array}{c}-.010 \\
.851\end{array}$ & 1 & & & & & & & \\
\hline $\mathrm{SPR} * \mathrm{OC} 1$ & $\begin{array}{l}.047 \\
.379\end{array}$ & $\begin{array}{c}-.084 \\
.199\end{array}$ & $\begin{array}{l}.003 \\
.955\end{array}$ & $\begin{array}{c}.808^{* *} \\
.000\end{array}$ & $\begin{array}{l}.005 \\
.915\end{array}$ & $\begin{array}{c}.204 * * \\
.000\end{array}$ & $\begin{array}{c}.472 * * \\
.000\end{array}$ & 1 & & & & & & \\
\hline $\mathrm{SPR} * \mathrm{OC} 2$ & $\begin{array}{l}.020 \\
.710\end{array}$ & $\begin{array}{r}-.845 \\
.119\end{array}$ & $\begin{array}{l}.046 \\
.391\end{array}$ & $\begin{array}{c}.468^{* *} \\
.000\end{array}$ & $\begin{array}{l}-.040 \\
.454\end{array}$ & $\begin{array}{l}.327 \\
.000\end{array}$ & $\begin{array}{l}.379 \\
.000\end{array}$ & $\begin{array}{l}.643 \\
.000\end{array}$ & 1 & & & & & \\
\hline $\mathrm{SPR} * \mathrm{OC} 3$ & $\begin{array}{l}-.018 \\
.731\end{array}$ & $\begin{array}{r}-.043 \\
.936\end{array}$ & $\begin{array}{l}.100 \\
.064\end{array}$ & $\begin{array}{c}.229 * * \\
.000\end{array}$ & $\begin{array}{l}-.057 \\
.287\end{array}$ & $\begin{array}{c}.965^{* *} \\
.000\end{array}$ & $\begin{array}{c}.187 * * \\
.000\end{array}$ & $\begin{array}{c}.316^{* * *} \\
.000\end{array}$ & $\begin{array}{c}.405^{* *} \\
.000\end{array}$ & 1 & & & & \\
\hline LISTED & $\begin{array}{l}.004 \\
.924\end{array}$ & $\begin{array}{c}-.100 * \\
.040\end{array}$ & $\begin{array}{r}-.073 \\
.134\end{array}$ & $\begin{array}{c}-.140 * \\
.004\end{array}$ & $\begin{array}{l}.125^{*} \\
.011\end{array}$ & $\begin{array}{c}-.368^{* *} \\
.000\end{array}$ & $\begin{array}{c}-.135^{*} \\
.012\end{array}$ & $\begin{array}{c}-.228 * * \\
.000\end{array}$ & $\begin{array}{c}-.241 * * \\
.000\end{array}$ & $\begin{array}{c}-.421^{* *} \\
.000\end{array}$ & * & & & \\
\hline LASSETS & $\begin{array}{l}.036 \\
.461\end{array}$ & $\begin{array}{l}-.022 \\
.528\end{array}$ & $\begin{array}{l}-.031 \\
.528\end{array}$ & $\begin{array}{l}.012 \\
.799\end{array}$ & $\begin{array}{l}.024 \\
.617\end{array}$ & $\begin{array}{l}.052 \\
.292\end{array}$ & $\begin{array}{l}.036 \\
.498\end{array}$ & $\begin{array}{l}.034 \\
.520\end{array}$ & $\begin{array}{l}.038 \\
.475\end{array}$ & $\begin{array}{l}.068 \\
.209\end{array}$ & $\begin{array}{r}-.085 \\
.084\end{array}$ & $\begin{array}{l}5 \\
4\end{array}$ & & \\
\hline $\begin{array}{c}\text { Bank } \\
\text { (z-score) }\end{array}$ & $\begin{array}{c}-.156^{* * *} \\
.001\end{array}$ & $\begin{array}{c}-.177 * * \\
.000\end{array}$ & $\begin{array}{c}-.260^{* *} \\
.000\end{array}$ & $\begin{array}{l}.098 \\
.051\end{array}$ & $\begin{array}{r}-.011 \\
.825\end{array}$ & $\begin{array}{c}-.163 * \\
.001\end{array}$ & $\begin{array}{l}-.074 \\
.183\end{array}$ & $\begin{array}{l}.037 \\
.501\end{array}$ & $\begin{array}{c}-.121^{*} \\
.028\end{array}$ & $\begin{array}{c}-.156^{* *} \\
.004\end{array}$ & $\begin{array}{l}-.051 \\
.305\end{array}$ & $\begin{array}{c}-.116^{*} \\
.02\end{array}$ & 1 & \\
\hline GDP/CAP & $\begin{array}{l}.013 \\
.786\end{array}$ & $\begin{array}{l}.063 \\
.196\end{array}$ & $\begin{array}{r}-.004 \\
.934\end{array}$ & $\begin{array}{c}-.111 * \\
.023\end{array}$ & $\begin{array}{l}.038 \\
.431\end{array}$ & $\begin{array}{l}-.062 \\
.2054\end{array}$ & $\begin{array}{l}.030 \\
.572\end{array}$ & $\begin{array}{l}-.047 \\
.382\end{array}$ & $\begin{array}{c}-.164 * * \\
.002\end{array}$ & $\begin{array}{l}-.081 \\
.133\end{array}$ & $\begin{array}{l}-.069 \\
.158\end{array}$ & $\begin{array}{l}-.008 \\
.856\end{array}$ & $\begin{array}{c}-.26 * * \\
.000\end{array}$ & 1 \\
\hline
\end{tabular}

Note. $(* *)$ indicates significant at $1 \%$ level; * indicates significance at $5 \%$ level (two-tailed).

\subsection{Ownership Concentration and Bank Risk-Taking}

We estimate a country random effect model using the Generalized Listed Square (GLS) method random effect (RE) technique following Baltagi and $\mathrm{Wu}$ (1999) procedure. This procedure is robust for first-order auto-regressive (AR (1)) disturbances within unbalanced-panels and heteroskedasticity across panels. The fixed effect is not feasible here because some variables of the model are the same for all banks from the same county (right protection index, GDP per capita, bank Z-score). Table 6 reports results of the empirical estimation of the model (1).

\subsubsection{Results for Assets Risk Ratio and Credit Risk}

As presented previously, we use three dummies indicating ownership concentration. First, we consider that there is concentrated ownership when one or more shareholders own more than $10 \%$ of the bank share (OC1). According to table 6 we find that ownership concentration has a positive and significant impact on the asset risk (SDROA and SDROE) and negative impact on Loan Loss Provision (LLP) ratio. Second, if ownership concentration is defined using a 25\% ownership stake (OC2), the results presented in table 6 show that ownership concentration has relatively less significant effect on bank asset risk and insolvency risk. Finally, if ownership concentration is defined using $50 \%$ ownership stake (OC3) we find that banks with concentrated ownership have higher level of risk-taking only for assets risk. These findings confirm our first hypothesis. Also, as minority investor's right increases, the impact of ownership concentration reduces. So ownership concentration matters less when the presence of regulatory control is stronger. This result is in line with the findings of Shehzad et al. (2010) and the view of Demzets and Lehn (1985).

\subsubsection{Results for the Z-Score Ratio}

The results of the impact of ownership concentration on bank insolvency ratio are presented in Table 6. It shows that ownership concentration (OC1) has no effect on bank stability. When ownership concentration is defined 
using a $25 \%$ ownership stake (OC2), we find that it has a negative effect on banks Z-score at the $10 \%$ level of significance, while, as shareholders protection rights increases the sensitivity of bank insolvability ratio to ownership concentration decreases. The same result shows up when ownership concentration is defined using 50\% ownership stake (OC3). This finding confirms the results of Shehzad et al. (2010).

We can conclude that the effects of ownership concentration on bank risk-taking in MENA region depends on the importance of the level of shareholder protection rights that can offer the domestic legal system to minority investors. If minority shareholders are highly protected by regulators, majority shareholders are incited to protect the interests of minority shareholders. In this case we talk about the convergence of shareholders (majority versus minority) interests.

Table 6. Estimation results of model 1

\begin{tabular}{|c|c|c|c|c|c|c|c|c|c|c|c|c|}
\hline \multirow{3}{*}{ Variables } & \multicolumn{6}{|c|}{ Asset Risk } & \multirow{2}{*}{\multicolumn{3}{|c|}{$\begin{array}{r}\text { Credit Risk } \\
\text { LLP }\end{array}$}} & \multirow{2}{*}{\multicolumn{3}{|c|}{$\begin{array}{r}\text { Default Risk } \\
\text { ZSCORE }\end{array}$}} \\
\hline & \multicolumn{3}{|c|}{ SDROA } & \multicolumn{3}{|c|}{ SDROE } & & & & & & \\
\hline & $\mathrm{OC} 1$ & $\mathrm{OC} 2$ & OC3 & $\mathrm{OC} 1$ & $\mathrm{OC} 2$ & OC3 & $\mathrm{OC} 1$ & $\mathrm{OC} 2$ & $\mathrm{OC} 3$ & $\mathrm{OC} 1$ & $\mathrm{OC} 2$ & OC3 \\
\hline \multirow{2}{*}{ OC } & $.010 * * *$ & $-.001 *$ & $.0105^{* * *}$ & $.02159 * *$ & .0008 & .0254 & $-.159 * *$ & -.002 & .00492 & -14.879 & $-3.653 *$ & -1.650 \\
\hline & .000 & .084 & .000 & .014 & .775 & .274 & .000 & .411 & .608 & .587 & .069 & .819 \\
\hline \multirow{2}{*}{ SPI } & $.001 * * *$ & .0003 & $.00129 * * *$ & $.028^{* *} *$ & .0013 & $.0039^{*}$ & -.0211 & $.008 * * *$ & $.0077 * * *$ & -1.0287 & $2.360 * * *$ & $2.120^{* *}$ \\
\hline & .008 & .391 & .008 & 014 & .543 & .088 & .004 & .000 & .000 & .859 & .004 &. .18 \\
\hline \multirow{2}{*}{$\mathrm{SPI} * \mathrm{OC}$} & $-.0018 * * *$ & .00002 & $-.0018 * * *$ & $-.0315^{* * *}$ & $-.00177 * * *$ & -.0053 & $.0309 * * *$ & $.00149 * * *$ & -.0006 & 4.044 & .489 & 1.432 \\
\hline & .002 & .833 & .002 & .007 & .005 & .237 & .000 & .000 & .761 & .488 & .230 & .356 \\
\hline \multirow{2}{*}{ LAssets } & $-.7^{\mathrm{e}-5 * *}$ & $-.6^{6-5 *}$ & $-.7^{\mathrm{e}-5 * *}$ & -.0006 & -.00006 & -.0006 & $-.0007 * * *$ & $-.4^{\mathrm{e}-5 * *}$ & $-.4^{\mathrm{e}-6 * * *}$ & .0046 & .004 & .004 \\
\hline & .045 & .056 & .045 & .356 & .341 & .343 & .000 & .050 & .038 & .134 & .126 & .194 \\
\hline \multirow{2}{*}{$\begin{array}{l}\text { Bank } \\
\text { (Z-score) }\end{array}$} & $-.7^{\mathrm{e}-5}$ & -.000016 & -.000007 & $-.0006^{* * *}$ & $-.0006^{* * *}$ & $-.00058^{* * * *}$ & $-.0007 * * *$ & $-.0006^{* * *}$ & $-.0006^{* * *}$ & .1093 & $.155^{*}$ & .145 \\
\hline & .978 & .571 & .978 & .000 & .000 & .000 & .000 & .000 & .000 & .218 & .091 & .112 \\
\hline \multirow{2}{*}{ GDP/CAPIT } & $.9^{\mathrm{e}-7 * * *}$ & $.1^{\mathrm{e}-5 * * *}$ & $.9^{\mathrm{e}-7 * * *}$ & $.1^{\mathrm{e}-6}$ & $.5^{\mathrm{e}-6}$ & $.1^{\mathrm{e}-6}$ & $-.1^{\mathrm{e}-6}$ & $.6^{\mathrm{e}-6 * * *}$ & $.6^{\mathrm{e}-6 * * *}$ & $-.0051 * * *$ & $-.0005 * * *$ & $-.0005 * * *$ \\
\hline & .005 & .003 & .005 & .702 & .839 & .511 & .355 & .003 & .007 & .000 & .000 & .000 \\
\hline \multirow{2}{*}{ Crisis } & .0003 & .0005 & .00037 & -.00151 & -.0029 & -.00161 & $-.0076 * * *$ & $-.008 * * *$ & $-.009 * * *$ & .9518 & 1.269 & 2.059 \\
\hline & .470 & .463 & .470 & .569 & .351 & .567 & .000 & .000 & .000 & .581 & .459 & .270 \\
\hline \multirow{2}{*}{ Constant } & -.00004 & $.0061 * * *$ & -.00004 & -.0684 & $-.0669 * * *$ & .04358 & $.170 * * *$ & .009 & $.013 * * *$ & 32.519 & $19.991 * * *$ & $17.435 * * *$ \\
\hline & .987 & .002 & .987 & .264 & .000 & .001 & .000 & .000 & .005 & .239 & .000 & .001 \\
\hline $\begin{array}{l}\text { Number of } \\
\text { Obser }\end{array}$ & 324 & 324 & 324 & 324 & 324 & 324 & 308 & 308 & 308 & 324 & 324 & 324 \\
\hline \multirow{2}{*}{ Chi2 } & 47.70 & 26.12 & 47.70 & 41.12 & 28.25 & 52.17 & 226.19 & 184.52 & 199.45 & 66.80 & 67.75 & 78.74 \\
\hline & .000 & .000 & .000 & .000 & .000 & .000 & .000 & .000 & .000 & .000 & .000 & .000 \\
\hline
\end{tabular}

Note. ${ }^{* * *}, * * *$ : Indicate statistical significance at the $1 \%, 5 \%$ and $10 \%$ level, respectively.

\subsection{Major Shareholders Identity and Bank Risk-Taking}

\subsubsection{Results of Two Groups Means Comparison Test}

\section{State versus private banks}

We began our empirical study with two groups' mean comparison test to identify statistically differences of our dependent variables between types of banks. Table 7 presents the two-group comparison test results. We find that state-owned banks are significantly more stable than private domestic banks. On average government-owned banks have a SDROE (Z-score) of 0.0402 (133.207) compared to 0.0815 (52.986) for the private banks. Sate banks have also lower credit risk than domestic banks. These findings support Beck et al. (2009), state banks are much larger and enjoy higher economic of scale as a result. Local governments are typically less diversified in their risk exposure, which might reduce their risk appétit (Beck et al., 2009). This result is examined in more detail in the next section using regression analysis. 


\section{Foreign private versus Domestic private banks}

Now the differences between foreign and domestic banks' risk-taking behavior would be analyzed. As shown in table 7 foreign banks are smaller, this fact it is due to their recent implementation into banking system in the region as proposed by Farazi et al. (2011). Foreign banks were significantly riskier than private domestic banks (at 5\% level), with higher SDROE (0.09541) compared to SDROE (0.05209) in domestic banks. However, foreign banks are significantly more solvent than domestic one and present less important credit risk.

Table 7. Bivariate comparison of bank risk measures by major shareholders identity

\begin{tabular}{|c|c|c|c|c|c|c|}
\hline \multirow{4}{*}{ Variables } & \multicolumn{2}{|c|}{ Panel 1} & \multicolumn{2}{|c|}{ Panel 2} & \multicolumn{2}{|c|}{ Panel 3} \\
\hline & \multicolumn{2}{|c|}{ (Government is excluded) } & \multicolumn{2}{|c|}{ (Domestic is excluded) } & \multicolumn{2}{|c|}{ (Foreign is excluded) } \\
\hline & DOMESTIC & FOREIGN & FOREIGN & GOVERNEMENT & DOMESTIC & GOVERNEMENT \\
\hline & \multicolumn{2}{|c|}{ (t-statistic) } & \multicolumn{2}{|c|}{ (t-statistic) } & \multicolumn{2}{|c|}{ (t-statistic) } \\
\hline \multirow{2}{*}{ Z-score } & 54.4886 & 59.5746 & 59.5146 & 150.103 & 54.4886 & 150.103 \\
\hline & \multicolumn{2}{|c|}{$-.3 .1677 * * *$} & \multicolumn{2}{|c|}{$-11.5469 * * *$} & \multicolumn{2}{|c|}{$-10.0448 * * *$} \\
\hline \multirow{2}{*}{ SDROA } & 0.0084427 & 0.0091165 & 0.009116 & 0.007237 & 0.0084427 & 0.0072375 \\
\hline & \multicolumn{2}{|c|}{$-2.9882 * * *$} & \multicolumn{2}{|c|}{$5.4395 * * *$} & \multicolumn{2}{|c|}{$3.8187 * * *$} \\
\hline \multirow{2}{*}{ SDROE } & 0.0119246 & 0.0954126 & 0.095412 & 0.035018 & 0.0419246 & 0.035018 \\
\hline & \multicolumn{2}{|c|}{$-18.0650 * * *$} & \multicolumn{2}{|c|}{$17.0996 * * *$} & \multicolumn{2}{|c|}{$5.6578 * * *$} \\
\hline \multirow{2}{*}{ LLP } & 0.056984 & 0.0612591 & 0.0612591 & 0.0168634 & 0.056984 & 0.0168634 \\
\hline & \multicolumn{2}{|c|}{$-1.788 * * *$} & \multicolumn{2}{|c|}{$126.1095 * * *$} & \multicolumn{2}{|c|}{$25.3805 * * *$} \\
\hline
\end{tabular}

Note. $* * *, * * *$ : Indicate statistical significance at the $1 \%, 5 \%$ and $10 \%$ level, respectively.

In summary, the results of bivariate analyses presented in Table 7 support our second hypotheses. To deepen our study, we want to investigate them in multivariate settings. Table 8 summarizes regression estimates results.

\subsubsection{Regression Results}

Columns 1 and 2 (Table 8) report the results for regression of assets risk. The dummy variable for domestic ownership is excluded. State ownership in column 2 is statistically significant (at least at $1 \%$ level) and has negative coefficient denoting that state-owned banks take less risk (SDROE) than private-domestic banks. State ownership in column 3 is statistically significant (at least at 1\% level) and has positive coefficient denoting that state-owned banks are more stable than private domestic banks. Further we find that government-owned banks have negative and significant (at least at 1\%) level effect on credit risk (LLP). Government-owned banks take less risk in the management of their credit portfolio than private-domestic banks. This result confirms the finding of Cornett et al. (2010) who find that government-owned banks tend to improve their credit management policy after Asian financial crisis.

Foreign variable has no significant effect on assets risk neither insolvency risk. So according to this result we can conclude that foreign-owned banks and domestic-owned banks accept the same level of assets and insolvency risk. Column 3 reports results for Z-score regression. Foreign ownership has positive effect on bank credit risk significant at $1 \%$ level. It is consistent with hypotheses 2, and confirms previous studies of Rokhim and Suanto (2011) and Unite and Sullivan (2003) realized respectively in Indonesia and in Philippine banking industry. The implementation of foreign ownership in domestic bank industry makes credit market tighter. In addition, foreign banks bring new management usually composed by foreign managers who are not well informed about the condition in countries where they operate. Due to their limited knowledge, managers may set inappropriate credit policy that leads to an increase of credit risk (Rokhim \& Susanto, 2011).

The listed dummy variable has significant effect on assets risk measures (SDROA/SDROE). This result indicates there is significant difference of assets risk between listed and unlisted banks. The size of bank has significant effect on bank assets risk. GCC variable exhibits significant negative effect on bank risks (credit risk, assets risk and insolvency risk). According to this result we conclude that banks operating in GCC countries take less risk than banks from other countries in MENA region. The GDP per capita variable has significant effect (at least at $5 \%$ level) and positive impact on bank risk-taking, denoting that banks operating in more developed countries are more risked than banks from the other countries. Further, crisis has no significant effect on banks' risk-taking behavior. 
Table 8. Estimation results of model 2

\begin{tabular}{|c|c|c|c|c|}
\hline \multirow[b]{2}{*}{ Variables } & \multicolumn{2}{|c|}{ Assets Risk } & \multirow{2}{*}{$\frac{\text { Default risk }}{\text { Z-score }}$} & \multirow{2}{*}{$\frac{\text { Credit Risk }}{\text { LLP }}$} \\
\hline & SDROA & SDROE & & \\
\hline \multirow{2}{*}{ Constant } & $0.0140 * * *$ & $0.07178 * * *$ & $26.481 * * *$ & $0.0435 * * *$ \\
\hline & 0.000 & 0.000 & 0.00 & 0.000 \\
\hline \multirow{2}{*}{ GOVERNMENT } & 0.00081 & $-0.0181 * * *$ & $6.3773 * * *$ & $-0.0191 * * *$ \\
\hline & 0.307 & 0.000 & 0.000 & 0.001 \\
\hline \multirow{2}{*}{ FOREIGN } & -0.0009 & 0.0067 & -2.2265 & $0.0138 * * *$ \\
\hline & 0.136 & 0.369 & 0.160 & 0.001 \\
\hline \multirow{2}{*}{ LISTED } & $-0.0012 *$ & $0.016108 * * *$ & $-7.8134 * * *$ & $-0.0069 * * *$ \\
\hline & 0.070 & 0.000 & 0.000 & 0.001 \\
\hline \multirow{2}{*}{ LAssets } & $-0.000001^{* * *}$ & -0.000003 & 0.00425 & $-0.4^{\mathrm{e}-6}$ \\
\hline & 0.003 & 0.680 & 0.270 & 0.932 \\
\hline \multirow{2}{*}{ Bank Z-score } & $-0.0001 * * *$ & $-0.00109 * * *$ & $0.3006^{* * *}$ & $-0.00034 * * *$ \\
\hline & 0.000 & 0.000 & 0.001 & 0.002 \\
\hline \multirow{2}{*}{ GDP/CAPITA } & $-0.3^{e-6}$ & $0.3^{\mathrm{e}-6}$ & -0.00007 & $0.3^{\mathrm{e}-7}$ \\
\hline & 0.207 & 0.004 & 0.335 & 0.826 \\
\hline \multirow{2}{*}{ CRISIS } & 0.00074 & -0.0032 & 2.3368 & 0.000948 \\
\hline & 0.137 & 0.349 & 0.122 & 0.646 \\
\hline \multirow{2}{*}{ GCC } & $-0.0017 * * *$ & $-0.01292 * * *$ & $4.2034 * *$ & $-0.00574 * * *$ \\
\hline & 0.017 & 0.000 & 0.047 & 0.007 \\
\hline \multirow{2}{*}{ Constant } & $0.0140 * * *$ & $0.07178 * * *$ & $26.481 * * *$ & $0.0435 * * *$ \\
\hline & 0.000 & 0.000 & 0.00 & 0.000 \\
\hline Number of observations & 411 & 412 & 408 & 386 \\
\hline Chi2 & 70.83 & 100.72 & 103.91 & 156.46 \\
\hline Prob $>$ chi 2 & 0.000 & 0.000 & 0.000 & 0.000 \\
\hline
\end{tabular}

Note. ***, ** and * represent significance at 1,5 and $10 \%$ level respectively.

\subsection{Shareholders Identity Combination and Banks'Risk-Taking Behavior}

Results presented in Table 9 confirm our second hypothesis (H2). We find that shares of capital held by different categories of shareholders impact significantly banks' risk-taking behavior. Studying the relation between ownership combination and bank risk-taking, we find that the proportion of total equity held by different categories of shareholders has significant effect on banks' risk-taking behavior.

Columns 1 to 3 of Table 9 report results for assets risk and credit risk measures. Column 3 shows that larger proportion of shares held by families is associated with higher credit risk (at the $1 \%$ level). Institutional investor variable has significant (at the 5\% level) and positive effects on bank assets risk. The positive relation is consistent with the findings of Iannotta et al. (2007), Leavine (1999) and Barry et al. (2011) who found a positive relationship between bank risk-taking measures (Assets risk) and institutional ownership. Additionally, director ownership has significant (at the 1\% level) and negative effect on bank credit risk, this relation can be explained by the fact that credit risk is directly affected by the management decisions.

Column 4 of Table 9 reports results for default risk measure. A higher stake of families has a negative but no significant effects on banks stability measure (Z-score). However, for institutional ownership variable, the relation is negative and significant (at the 1\% level). Institutional-owned banks are less stable than other banks (Leavine, 1999; Iannotta et al., 2007; Barry et al., 2011).

\subsection{Deeper Investigations}

To further examine issues related to the influence of ownership structure on banks' risk-taking behavior, we check for deeper investigation. We estimate the impact of ownership nature on the bank risk as presented in Model 3 and we test whether publicly held banks behave differently than privately owned banks by including in model 3 presented below an interaction variable that permit to estimate the relationship between ownership nature and risk if bank is LISTED. We use the following econometric model. 


\section{Model 4}

$$
\begin{aligned}
& \text { RISK }_{i t}=\lambda_{0}+\beta_{1} \text { Manager }_{i t}+\beta_{2} \text { Directors }_{i t}+\beta_{3} \text { Family }_{i t}+\beta_{4} \text { Institutional }_{i t}+\beta_{5} \text { Institutional }^{*} \text { LISTED }_{i t}+
\end{aligned}
$$



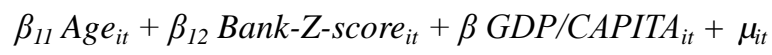

Market exposure should influence the behavior of publicly held banks (Barry et al., 2011). Market discipline should impose strong incentives on banks to conduct their business in a minimum level of safety, including an incentive to maintain high level of equity capital to face potential future losses. While, publicly held banks have the opportunity to access to additional equity at a lower cost than privately owned banks. Consequently, listed banks have a higher degree of freedom to manage their equity; which gives them the flexibility to invest in risky projects characterized by a higher expected return. So according to, Barry et al. (2011) the expected sign associated with the variable LISTED is irresolute. Therefore, we can expect two effects from market discipline, on the behavior of publicly held banks, when market forces moderate the incentives of bank dominated by categories of shareholders that are rationally inclined to take higher risk such as institutional investors, in this case we can expect a decrease in risks. When market forces might align the objectives of publicly held banks to generate faster growth and higher returns, an increase in risks can be expected.

Table 9. Influence of ownership structure on banks' risk-taking behavior of listed and unlisted banks (models 3 and 4)

\begin{tabular}{|c|c|c|c|c|c|c|c|c|}
\hline \multirow{2}{*}{ Variables } & \multicolumn{2}{|c|}{ Assets Risk } & \multirow{2}{*}{$\begin{array}{c}\text { Credit risk } \\
\text { LLP }\end{array}$} & \multirow{2}{*}{$\begin{array}{c}\text { Default risk } \\
\text { Z-score }\end{array}$} & \multicolumn{2}{|c|}{ Assets Risk } & \multirow{2}{*}{$\begin{array}{c}\text { Credit risk } \\
\text { LLP }\end{array}$} & \multirow{2}{*}{$\frac{\text { Default risk }}{\text { Z-score }}$} \\
\hline & SDROA & SDROE & & & SDROA & SDROE & & \\
\hline \multirow{2}{*}{ Constant } & $.01502 * * *$ & $.0828 * * *$ & $.04665 * * *$ & $29.7497 * * *$ & $.01601 * * *$ & $.08928 * * *$ & $.0356^{* * * *}$ & $2.21766^{*}$ \\
\hline & .000 & .000 & .000 & .003 & .000 & .000 & .000 & .069 \\
\hline \multirow{2}{*}{ INSTITUIONAL } & $.0032 * *$ & $-.0276^{* * *}$ & -.0055 & $-16.385^{* *}$ & $-.01455^{* * *} *$ & $-.0311 * *$ & -.0002 & -8.4482 \\
\hline & .045 & .000 & .287 & .010 & .000 & .019 & .981 & .565 \\
\hline \multirow{2}{*}{ FAMILY } & .0018 & -.0115 & $.0254 * * *$ & -2.8528 & $-.00625 * * *$ & $-.02766^{* * * *}$ & $.06775 * * *$ & 1.1829 \\
\hline & .316 & .132 & .001 & .756 & .007 & .000 & .000 & .274 \\
\hline \multirow{2}{*}{ MANAGER } & .0012 & -.0196 & .0058 & -66.5896 & -.05084 & .02973 & .03213 & $37.6424 * *$ \\
\hline & .240 & .302 & .771 & .455 & .111 & .457 & .748 & .012 \\
\hline \multirow{2}{*}{ DIRETORS } & -.0013 & .0211 & $-.0259 * * *$ & -3.7052 & $.15163 * *$ & -.08384 & -.10347 & $-6.0113 * * *$ \\
\hline & .426 & .147 & .000 & .755 & .035 & .291 & .584 & .001 \\
\hline INSTITUIONAL * & \multirow{2}{*}{-} & \multirow{2}{*}{ - } & \multirow{2}{*}{-} & \multirow{2}{*}{ - } & $.02401 * * *$ & .00701 & -.00604 & -3.0412 \\
\hline LISTED & & & & & .000 & .656 & .561 & .866 \\
\hline \multirow{2}{*}{ FAMILY * LISTED } & \multirow{2}{*}{ - } & \multirow{2}{*}{ - } & \multirow{2}{*}{-} & \multirow{2}{*}{ - } & $.01213 * * *$ & $.0581 * * *$ & $-.107014 * * *$ & -1.9041 \\
\hline & & & & & .000 & .000 & .000 & .337 \\
\hline \multirow{2}{*}{ MANAGER * LISTED } & \multirow[b]{2}{*}{ - } & \multirow[b]{2}{*}{ - } & \multirow{2}{*}{-} & \multirow{2}{*}{ - } & $.06395 *$ & -.0059 & -.0635 & $-5.8867 * * *$ \\
\hline & & & & & .062 & .920 & .518 & .004 \\
\hline \multirow{2}{*}{ DIRETORS *LISTED } & \multirow{2}{*}{ - } & & & & $-.15537 * *$ & .10781 & .0801 & $6.8192 * * *$ \\
\hline & & - & - & - & .031 & .179 & .671 & .001 \\
\hline ISTFD & $-.0016^{* * * *}$ & $.0106^{* * * *}$ & -.0013 & -7.6915 & $-.0053 * * *$ & .0025 & $.01214 * * *$ & .38317 \\
\hline LIS IED & .006 & .001 & .541 & .397 & .000 & .574 & .000 & .968 \\
\hline$A G F$ & $-.0005 * * *$ & $.0001 * *$ & .00002 & -.0271 & $-.000066^{* * * *}$ & .00017 & $.00006^{*}$ & -.0188 \\
\hline AGE & .000 & .022 & .612 & .729 & .000 & .044 & .094 & .823 \\
\hline I A scets & $-.000001^{* *}$ & -.000009 & -.000003 & .0049 & $-.000001 * *$ & -.000009 & -.0000002 & .0576 \\
\hline LAssels & .043 & .150 & .385 & .583 & .015 & .102 & .616 & .552 \\
\hline P & $-.0001 * * *$ & $-.00152 * * *$ & $-.000488 * * *$ & $.6364 * * *$ & $-.00005^{*}$ & $-.00158 * * *$ & $-.00054 * * *$ & $.70239 * * *$ \\
\hline Bank Z-score & .000 & .000 & .000 & .000 & .044 & .000 & .000 & .001 \\
\hline GDP/CAPITA & $-.000001 * * *$ & -.0000004 & $-.0000005^{* * *}$ & -.0003 & $-.1 \mathrm{e}-7 * * *$ & $-.0000003 * * *$ & $-.0000002 * * *$ & -.0003 \\
\hline GDP/CAPIIA & .000 & $.000 * * *$ & .000 & .137 & .000 & .002 & .007 & .198 \\
\hline Nbr of observations & 383 & 384 & 358 & 380 & 383 & 384 & 358 & 380 \\
\hline Chi2 & 74.82 & 88.03 & 10.88 & 44.47 & 176.27 & 127.79 & 153.67 & 43.45 \\
\hline Prob $>$ chi20 & .000 & .000 & .000 & .000 & .000 & .000 & .000 & .000 \\
\hline
\end{tabular}

Note. $* * *, * *$ and $*$ represent significance at 1,5 and $10 \%$ level respectively. 
Table 9 presents, also, respectively results of assets risk, credit risk and default risk. It provides results about the effect of market discipline by considering the interaction between the proportion of equity held by each category of owners and the exposure of banks to market forces (ownership*listed). First, as shown in column2 institutional ownership has negative effect on assets risk (SDROE) and credit risk (LLP)

Columns 5 and 6 for unlisted banks, we find that family and institutional ownership have significant (at the level of $1 \%$ ) and negative effect on assets risk (SDROE and SDROA). Despite, the relation between credit risk and family ownership is positive and significant (column 7). In addition, we find a positive (vs. negative) and significant relationship between managers (vs. directors) ownership and banks' default risk measure (Z-score). However, for listed banks, family ownership has significant and positive effect on bank risk measure (SDROE and SDROA). This effect is negative for credit risk. We conclude that family ownership attitude vary significantly if banks are listed or unlisted. Institutional ownership has no significant effects on bank credit risk and assets risk. Manager (vs. director) ownership has significant (at the 1\% level) negative effect on bank default risk measure (Z-score). We note that the attitude of managers against risk taking vary according to the fact that banks are listed or not.

When we test the impact of market exposure, we find that unlisted banks have higher level of freedom to manage their equity which gives them the flexibility to invest in risky projects with higher expected returns essentially for family-owned banks. However, to some extent, credit risk and default risk are lower in listed banks when family owns an important part of banks' equity. Additionally, the effect of institutional investors in determining or controlling bank risk is less important for listed banks.

\section{Conclusion and Recommendations}

This paper examines whether different ownership structures are associated with different levels of risk in both publicly and privately held banks for a sample of about 72 banks from 10 countries in MENA region. We determine three levels of ownership concentration $(10 \%, 25 \%$ and $50 \%)$ that are assumed to have different risk-taking behaviors. We find that ownership concentration significantly affects bank risk (credit risk, insolvency risk and assets risk), while the effect differ depending on the level of ownership concentration. For credit risk ratio, the effect ownership concentration $(10 \%)$ is negative, while its effect is positive on assets risk at least if ownership is above $50 \%$ of the share. The relation between ownership concentration and bank risk-taking is affected by the legal environment. As argued by Demsetz and Lehn (1985) and Shehzad et al. (2010), ownership concentration matter less in regulated firms. Studying the effect of ownership nature on bank risk-taking, we differentiate in a first step of analysis three main categories of major owners, and we classify banks as follows: government-owned banks; Foreign-owned banks and private-domestic banks. We find that government-owned banks adopt avers risk politics comparing to foreign and private-domestic banks. In a second step, we differentiate four categories of shareholders that are assumed to have different risk-taking incentives (family, institutional, managers, and directors). Our aim is also to analyze whether different ownership combinations of commercial banks from MENA region can affect their politics in terms of risk-taking. We show that institutional ownership has significant effect only on assets risk, but family ownership has negative and significant effect on credit risk. This result is consistent with the conjecture that family members allow themselves to engage in investment with highly-value added and they employ their banks to finance projects of related parties (family members). Managers' ownership variable has no significant effect on risk; however directors' ownership variable has negative and significant effect on credit risk ratio. We further find that the relation between proportion of shares held by own category of shareholder presented above and bank risk-taking vary significantly according to the fact that bank is listed or unlisted. This is relatively important especially for the case of family ownership. When we test the impact of market discipline (listed/unlisted banks) we find that listed banks take more risk than unlisted banks. However, if banks are listed family ownership effect on credit risk become negative. We conclude that the impact of family ownership on bank credit risk vary according the fact that the bank is listed or unlisted.

The problematic of ownership structure is usually discussed in the international context but still not well developed in MENA economies especially, when we talk about bank sector. Noting that countries from MENA region know actually main economic and financial disturbance due to the political phenomenon of "Arab Spring", a closer examination of the same question during and after the "Arab Spring" would be worthwhile.

\section{References}

Anderson, R. C., \& Fraser, D. R. (2000). Corporate control, bank risk-taking, and the health of banking industry. Journal of Banking and Finance, 4, 1383-1398. http://dx.doi.org/10.1016/S0378-4266(99)00088-6

Baltagi, B. H., \& Wu, P. X. (1999). Unequally spaced panel data regressions with AR(1) disturbances. 
Econometric Theory, 15, 814-823. http://dx.doi.org/10.1017/S0266466699156020

Barry, T., Lepetit, L., \& Tarazi, A. (2011). Ownership structure and risk in publicly held and privately owned banks. Journal of Banking and Finance, 35, 1327-1340. http://dx.doi.org/10.1016/j.jbankfin.2010.10.004

Bennaceur, S., \& Goaied, M. (2008). The determinant of commercial bank interest margin and profitability: Evidence from Tunisia. Working Paper. Retrieved from http://papers.ssrn.com/sol3/papers.cfm?abstract_id=1538810

Berger, A., Clarke, G., Cull, R., Klapper, L., \& Udell, G. (2005). Corporate governance and bank performance: A joint analysis of the static, selection, and dynamic effects of domestic, foreign, and state ownership. Journal of Banking and Finance, 29, 2179-2221. http://dx.doi.org/10.1016/j.jbankfin.2005.03.013

Berger, A., Klapper, L., Peria, M., \& Zaidi, R. (2007). Bank ownership type and banking relationships. Journal of Financial Intermediation, 1-26. http://dx.doi.org/10.1016/j.jfi.2006.11.001

Burkart, M., Gromb, D., \& Panunzi, F. (1997). Large shareholders, monitoring, and the value of the firm. Quarterly Journal of Economics, 112, 693-728. http://dx.doi.org/10.1162/003355397555325

Chen, C. R., Steiner, T. L., \& Whyte, A. M. (1998). Risk taking behavior and management ownership in depository institution. Journal of Financial Research, 21, 1-16.

DeAngelo, H., \& DeAngelo, L. (1985). Managerial ownership of voting rights. Journal of Financial Economics, 14, 33-69. http://dx.doi.org/10.1016/0304-405X(85)90043-1

Demsetz, H., \& Lehen, K. (1985). The structure of corporate ownership: Causes and consequences. Journal of Political Economy, 93, 1155-1177. http://dx.doi.org/10.1086/261354

Elyasiani, E., \& Jia, J. J. (2008). Institutional ownership stability and BHC performance. Journal of Banking and Finance, 32(9), 1767-1781. http://dx.doi.org/10.1016/j.jbankfin.2007.12.010

Farazi, S., Fayen, E., \& Rocha, R. (2011). Bank ownership and performance in Middle East and North Africa. Policy Research Working Paper 5620. http://dx.doi.org/10.1596/1813-9450-5620

Gordon, G., \& Rosen, R. (1995). Corporate control, portfolio choice and the decline of banking journal. Journal of Finance, 50, 509-527. $\quad$ Retrieved from http://onlinelibrary.wiley.com/doi/10.1111/j.1540-6261.1995.tb05183.x/abstract

Haw, I. M., Ho, S., Hu, B., \& Wu, D. (2010). Concentrated control, institutions, and banking sector: An international study. Journal of Banking and Finance, 34, 485-497. http://dx.doi.org/10.1016/j.jbankfin.2009.08.013

Iannotta, G., Nocera, G., \& Sironi, A. (2007). Ownership structure, risk and performance in European banking industry. Journal of Banking and Finance, 31, 2127-2149. http://dx.doi.org/10.1016/j.jbankfin.2006.07.013

Isik, I., Gunduz, L., \& Omran, M. (2004). Managerial and scale efficiency in the MENA banking: A panel study of the Jordanian banking sector. http://dx.doi.org/10.2139/ssrn.494224

James, H. (1999). Owner as manager, extended horizon and the family firm. International Journal of the Economics of Business, 6, 41-56. http://dx.doi.org/10.1080/13571519984304

Jensen, M. C., \& Meckling, W. H. (1976). Theory of the firm: Managerial behavior, agency cost and ownership structure. Journal of Financial Economics, 3, 305-360. http://dx.doi.org/10.1016/0304-405X(76)90026-X

Kobeissi, N., \& Sun, X. (2010). Ownership structure and bank performance: Evidence from the Middle East and North Africa Region. Comparative Economic Studies, 52(3), 287-323. http://dx.doi.org/10.1057/ces.2010.10

Laeven, L., \& Levine, R. (2009). Bank governance, regulation and risk taking. Journal of Financial Economics, 93, 259-275. http://dx.doi.org/10.1016/j.jfineco.2008.09.003

Leven, L. (1999). Risk and efficiency in East Asian banks. World Bank Discussion Paper No. 2255. http://dx.doi.org/10.1596/1813-9450-2255

Micco, A., Panizza, U., \& Yanes, M. (2004). Bank ownership and performance Inter-American development bank. Working paper, $\mathrm{N}^{\circ} 518$. http://dx.doi.org/10.1596/1813-9450-3355

Morck, R., Stangeland, D., \& Yeung, B. (2000). Inherited wealth, corporate control, and economic growth: The Canadian disease. In Morck, R. (Ed.), Concentrated corporate ownership. National Bureau of Economic Research Conference, University of Chicago Press, Chicago. http://dx.doi.org/10.7208/chicago/9780226536828.001.0001 
Pound, J. (1988). Proxy contests and the efficiency of shareholder oversight. Journal of Financial Economics, 20, 237-266. http://dx.doi.org/10.1016/0304-405X(88)90046-3

Rokhim, R., \& Susanto, A. (2011). The increase of foreign ownership and its impact to the performance, competition \& risk in Indonesian banking industry. SSRN Working Paper. http://dx.doi.org/10.2139/ssrn.1915234

Roy, A. D. (1952). Safety first and the holding of assets. Econometrica, July, 431-450. http://dx.doi.org/10.2307/1907413

Saunders, A., Strock, E., \& Travlos, N. (1990). Ownership structure, deregulation, and bank risk taking. Journal of Finance, 45(2), 643-654. http://dx.doi.org/10.1111/j.1540-6261.1990.tb03709.x

Shehzad, C. T., De Haan, J., \& Scholtens, B. (2010). The impact of ownership concentration on impared loan and capital adequacy. Journal of Banking and Finance, 34, 399-408. http://dx.doi.org/10.1016/j.jbankfin.2009.08.007

Shleifer, A., \& Vishny, R. (1986). Large shareholders and corporate control. Journal of Political Economy, 94, 461-488. http://dx.doi.org/10.1086/261385

Shleifer, A., \& Vishny, R. (1997). A survey of corporate governance. Journal of Finance, 52(2), 737-783. http://dx.doi.org/10.1111/j.1540-6261.1997.tb04820.x

Srairi, S. (2013). Ownership structure and risk-taking behavior in conventional and Islamic banks: Evidence for MENA countries. Borsa Istanbul Review, 13, 115-127. http://dx.doi.org/10.1016/j.bir.2013.10.010

Stein, J. C. (1988). Takeover threats and managerial myopia. Journal of Political Economy, 96, 61-68. http://dx.doi.org/10.1086/261524

Stein, J. C. (1989). Efficient capital markets, inefficient firms: A model of myopic corporate behavior. Quarterly Journal of Economics, 104, 655-669. http://dx.doi.org/10.2307/2937861

Turk-Ariss, R. (2008). Financial liberalization and bank efficiency: Evidence from Post-war Lebanon. Applied Financial Economics, 18, 931-946. http://dx.doi.org/10.1080/09603100701335408

Unite, A. A., \& Sullivan, M. J. (2003). The effect of foreign entry and ownership structure on the Philippine domestic banking market. Journal of Banking and Finance, 27, 2323-2345. http://dx.doi.org/10.1016/S0378-4266(02)00330-8

\section{Copyrights}

Copyright for this article is retained by the author(s), with first publication rights granted to the journal.

This is an open-access article distributed under the terms and conditions of the Creative Commons Attribution license (http://creativecommons.org/licenses/by/3.0/). 